\title{
28 Research Suare \\ The effect of thranekron and autograft bone on bone defect healing in rabbit model
}

\section{Siavash Sharifi}

Shahrekord University Faculty of Veterinary Medicine

Amin Bigham-Sadegh ( $\nabla$ dr.bigham@gmail.com )

Shahrekord University Faculty of Veterinary Medicine https://orcid.org/0000-0003-4981-7495

Ahmad Oryan

Shiraz University School of Veterinary Medicine

Yasmin Alavi

Shahrekord University Faculty of Veterinary Medicine

Research article

Keywords: Thranekron, Bone repair, Autograft, Rabbits

Posted Date: March 17th, 2020

DOI: https://doi.org/10.21203/rs.2.18822/v2

License: (9) This work is licensed under a Creative Commons Attribution 4.0 International License.

Read Full License 


\section{Abstract}

Nowadays, bone grafting is used in both human and veterinary orthopedics to stimulate fracture healing, accelerate arthrodesis, and to restore bone defects. In such procedures, orthopedic surgeons are searching to favorable substitute for autograft bone. The present study seeks to investigate the use of Theranekron in bone defect healing process. 20 native rabbits (male rabbits weighing approximately $2 \mathrm{~kg}$ and aged 1.5-2 years) were divided into 4 groups of five, and bone fragments were removed from their radius bones. In the first group, Theranekron $1 \mathrm{mg} / \mathrm{kg}$ was injected into bone defect. Normal saline was injected into the same site of the five rabbits in the second group (saline treated controls). As for the third group (the untreated controls), nothing was injected. In the fourth group (autograft group), the removed bone was put in place and muscle and skin were sutured. Post op lateral x-rays were prepared on days 14 , 28,42 , and 56 . Bone biopsy for histopathological study was performed after 8 weeks. Radiographs and samples were analyzed statistically in terms of union, osteogenesis activity, and bone Remodeling. Results: Radiological evaluation showed that autograft group was significantly superior to both untreated and saline treated controls $(p=0.02, p=0.04$, respectively). Also, Theranekron group proved better than untreated controls $(p=0.04)$. Histopathological evaluation showed terabecular bone and bone marrow formations in Theranekron and also autograft groups. In the untreated and saline treated controls, most part of defect was filled with fibrous tissue. Conclusion: Theranekron treated group showed almost similarly to autograft counterpart, but better than normal saline and untreated controls. Keywords: Thranekron, Bone repair, Autograft, Rabbits

\section{Background}

Bone graft is currently used to treat fractures, accelerate joint union, and restore the bone defects. Autograft is considered the gold standard in such operative procedures, because it contains repair stimulating substances and the cells within does not provoke immune responses nor cause the transmission of contagious diseases [1]. In small animals, autograft bone is harvested from the iliac crest, the inner surface of the upper end of the tibia as well as humerus; while in humans iliac crest bone is used. Complications such as pain, infection, fracture, blood loss and need for further operative procedures are associated with autograft bone harvesting while there is a limited amount of bone for that purpose [2]. Given such problems associated with autografting bone, the use of non-autogrfat bones including allograft and xenograft is more favored in current orthopedics for some reasons as follows: there is no limit to these non-autogrfat bones and they contain cells and proteins which enhance healing; a supportive scaffold is formed within the huge gaps when tumors are removed and bone tissue is lost [3]. However, there is the risk of contagious diseases transmission when using allograft. Tarantula cubensis is an extract widely used in the treatment of tumors, abscesses, septicemia and toxemic conditions [4-6]. Reports indicate that it is helpful to bovine wound healing on day 14 , leading to reduced inflammation and epithelialization[7, 8]. Moreover, the extract reportedly reduces a wide range of infections $[9,10]$. Tarantula cubensis come from mygalomorph order/genus and is referred to as brown, hairy spider or mygalocubensis [11]. It is native to South Carolina, Texas and Cuba. Tarantula is brown 
and hairy and of less toxicity, compared to Tarantula hispanica. The basic composition of the extract is prepared from the whole spider, with arachnid as its main elementln doing so, the whole spider is initially crushed and an alcoholic extract with trade name Theranekron is produced [11]. investigated the effects of lavamisole and theranekron on skin papilloma and concluded that the former was more effective [10]. Gultiken, Vural, 2007 demonstrated that Theranekron was effective against breast benign tumors in dogs [5]. Albay Ahinduran et al , 2010 investigated the effects of this agent on the mouth ulcers due to bluetongue in cattle and revealed that the treatment improved food intake and appetite, reduced oral inflammation and decreased leukocyte and lymphocyte counts in CBC within 24 hours. Nonetheless, no change was evident after 10 days in the clinical findings and leukocyte counts and only a significant change was observed in lymphocyte count [8].

Sardari and colleagues in 2011 carried out a study on the effect of Theranekron on horse serum hematological and biochemical properties and concluded that most of the observed changes in hematological and biochemical parameters were statistically significant. Also, Theranekron treatment in the experimental horses yielded no adverse reaction [7].

Oryan et al, 2012, investigated the effect of Theranekron on the damaged tendon and showed an improvement in biomechanical parameters in the treatment group [12]. It has also been claimed that it reduces inflammation and stimulates re-epithelialization of the full thickness cutaneous wounds in cows during the first 14 days after injury $[7,8]$ and enhances healing or resolution of infection in a wide range of lesions [9]. In the present study attempts to investigate the healing potential of Theranekron was evaluated in a rabbit critical-sized radial defect model.

\section{Methods}

In total, 20 native male rabbits weighing approximately $2 \mathrm{~kg}$ and aged $1.5-2$ years were selected for surgical operations. The rabbits were purchased from local private farm. They were placed in a special cage for 15 days to let them adjust to the new conditions and were fed with special foods. Conditions and feeding were the same for all the rabbits. Ivermectin, an antiparasitic drug was injected subcutaneously $0.2 \mathrm{mg} / \mathrm{kg}$ to remove internal and external parasites of ringworm type. All animals received humane care in compliance with the Guide for Care and use of Laboratory animals $(\mathrm{NIH}$ publication No. 85-23, revised 1985). The study was approved by the local Ethics Committee of our Veterinary School. They were killed by intra-cardiac injection of $1 \mathrm{mg} / \mathrm{kg}$ Gallamine triethiodide (Specia Co., Paris, France).

The rabbits were divided into four groups of five and Theranekron (Richter Pharma, Wels, Austria) diluted $1 \mathrm{mg} / \mathrm{ml}$ in normal saline $0.9 \%$ was injected $1 \mathrm{mg} / \mathrm{kg}$ into the lesion sites of the five rabbits. Injections were performed on days 3,5,7 following the operations [12]. The 5 rabbits in normal saline treated control group received saline with Theranekron dose on the above-mentioned days.

In the untreated control group of rabbits, no injection was performed. Finally, in the autograft group, the harvested bone was put in place and the skin and muscle were sutured. The rabbits were sedated with 
acepromazine $2 \mathrm{mg} / \mathrm{kg}$ and anesthetized with ketamine $(30 \mathrm{mg} / \mathrm{kg} \mathrm{IM}$, xylazine $5 \mathrm{mg} / \mathrm{kg} \mathrm{IM}$ ) and diazepam (4mg/kg, IM) [13]. Their right forelimbs were shaved and prepared for the operation. After toweling, skin incision was made on the anterior-medial surface of the radius bone so that the bone was exposed and a piece of radius bone about $10 \mathrm{~mm}$ in size, (twice as long as the width), was accessed from medial site. First the defected area was covered by suturing the muscles over the bone defect with 30 Vicryl suture material and then skin was sutured with 2-0 nylon suture. The rabbits were left in the cage without external fixation till full recovery. All the rabbits received daily doses of intramuscular $5 \%$ Enrofloxacin $(5 \mathrm{mg} / \mathrm{kg})$ for 3 post-operative days.

\section{Clinical Evaluation}

To evaluate their clinical status, rabbits were examined twice a day and the operation site was checked regularly as well as using their hands, weight gaining, topical wound healing, inflammation and infections.

\section{Radiological Evaluation}

Lateral hand x-ray was prepared post operation on days $14,28,42$, and 56 . Radiographs were taken by Philips Xray machine with exposure parameters of $45 \mathrm{KVP}, 20 \mathrm{mAm} / \mathrm{s}$ and distance between the radiographic film and the X-ray source was about $70 \mathrm{~cm}$. Grid cassette (Fujifilm, USA) and standard radiography film were used. Lane and Sandhu modified scoring system was used for the evaluation and grading of the obtained radiographs [14].

\section{Histopathological Evaluation}

On day 56, all the rabbits were euthanized using anesthetic induction with a high level of magnesium sulphate cardiac injection. Then, the radius bone in all the rabbits was removed and the surrounding soft tissues were separated. Bones with defect were placed in Formalin 10\% (Merk, Germany) and sent to the lab for histopathological examination. Samples were stored in the formalin $10 \%$ for one day, then formalin was replaced and samples again stored in it till fixation. To demineralize the bones, they were stored in nitric acid (\%10) for 4 days, followed by washing with water and analyzed by an autotechnicon. To prepare microscopic slides, they were sent to histopathology lab to be examined by light microscopy. Emery histopathological scoring system was used for analysis. This scoring system is, as follows: zero points if the defect is empty, one point if the defect is filled only with fibrous connective tissue, two points if the fibrosis tissue is dominant in the combination of fibrosis tissue and fibrocartilage, three points if the fibrocartilage tissue is dominant in the combination of fibrosis tissue and fibrocartilage, four points if there is only the fibrocartilage tissue, five points if the fibrocartilage tissue exist along with the bone tissue and the fibrocartilage tissue is dominant, six scores, if the fibrocartilage tissue is along with bone tissue and the bone tissue, is dominant, and seven scores if the defect has only bone tissue [15].

\section{Statistical Analysis}


To analyze the obtained data, SPSS, and Kruskal-Wallis non parametric ANOVA were used. In case of $P<0.05$, Mann-Whitney was used to reanalyze the data. Level of significance was set at $P<0.05$. Statistical analyses were performed by SPSS software, version 16.0 (SPSS, Inc, Chicago, USA).

\section{Results}

Observations revealed no surgical wound infection. Radiographic evaluation of bone regeneration in rabbits was performed on days $14,28,42$, and 56 in the four groups of rabbits, i.e., autograft, Theranekron, untreated controls, and normal saline treated controls. Grading was performed for bone healing criteria as mentioned in table 1 and sum of them were used for statistical analysis.

In the $2^{\text {nd }}$ postoperative week, autograft group was significantly superior to both untreated and saline treated controls in radiographical criteria $(p=0.02, p=0.04$, respectively). Also, Theranekron group showed superior bone formation in comparison to untreated control $(p=0.04)$, (table 2, Fig. 1$)$

In the $4^{\text {th }}$ week, Theranekron group was significantly superior to both untreated and saline treated controls ( $p=0.03, p=0.02$, respectively) (table 2 , Fig. 2)

Similar to the $4^{\text {th }}$ week, in the $6^{\text {th }}$ week, Theranekron proved better $(p=0.006, p=0.008$, respectively) while autograft group was superior to saline treated controls ( $p=0.01$ ) ( Table 2, Fig. 2 and 4)

In the $8^{\text {th }}$ week, autograft group was superior to saline, untreated controls and Theranekron group ( $p=0.009, p=0.006, p=0.006$, respectively) ( Table 2, Fig. 6)

According to histopathological evaluation, there is no sign of inflammation or infection was at $56^{\text {th }}$ postoperative day. In Theranekron group 4 rabbits showed terabecular bone and bone marrow formations and one rabbit showed more cartilage than bone formation. Theranekron group was significantly superior than untreated and saline group on $56^{\text {th }}$ postoperative day $(p=0.004$, Table 3$)$. In autograft group cortical bone formation with remodeling and bone marrow formation was prominent in all five rabbits. Autograft group was superior to untreated and saline group in statistical analysis $(p=0.004$, Table 3$)$. In the untreated and saline treated controls, most part of defect in rabbits was filled with fibrous tissue rather than cartilage or bone tissues and were significantly inferior to autograft and theranekron groups (Table 3). There were no significant differences between autograft and theranekron groups on $56^{\text {th }}$ postoperative day.

Similar to radiological results, histopathological results were also statistically analyzed using kruscalwallis non parametric ANOVA followed by Mann Whitney $U$ test. As shown, a significant difference was only between untreated controls and two groups of Theranekron and autograft. Accordingly, untreated control group was inferior to autograft group $(p=0.004)$ and Theranekron group (Table 3, Fig 5).

\section{Discussion}


It is suggested that investigation of bone defect healing be conducted on rabbits rather than rats (Rats and mice have a healing process that is different from humans, since they haven't a Harvesian bone system) [16], In addition rabbits long bones have the Harvesian bone system which is similar to human's, so the kind of bone healing after a fracture is very similar to human's one ; therefore, rabbits can serve as a good model for the studies addressing fracture healing [16].

In this study, bone autografting and theranekron injection (in defected site) were carried out using rabbit animal model. Since the radius and ulna are joined in rabbits the defect could create on radius bone with no need to fixation, so bone healing procedure could evaluated without interfering of fixation instrument [17]. The defect was made on the mid radius bone with the harvested bone length being twice the width of bone diaphysis to produce the critical nonunion bone model [18]. Autograft group in the present study performed the best in terms of healing pace, compared to other groups and Theranekron group functioned similarly to autograft counterpart. Autograft is considered the gold standard in bone regenerating procedures, because it contains repair stimulating substances and the cells within does not provoke immune responses nor cause the transmission of contagious diseases [1]. In small animals, autograft bone is harvested from the iliac crest, proximal metaphysis of the tibia as well as humerus, while in humans iliac crest bone is used. Complications such as pain, infection, fracture, blood loss and need for further operative procedures are associated with autograft bone harvesting while there is a limited amount of bone for that purpose [2]. Therefore, in our study, autograft transplant is considered as a positive control group for comparison to other groups.

Theranekron group was almost the same as autograft group but better in comparison with normal saline treated and untreated control groups. The beneficial effect theranekron on bone regeneration could be explained by reducing role of theranekron in inflammatory phase and as well as accelerating of fibroplasia at stage of repairing [19]. It has been reported significant reduced inflammatory cells in Theranekron treated group, compared to the controls, while a significant increase in collagen content was evident in wound healing model $[7,12]$.

Oryan, Moshiri et al, 2012 was demonstrated positive effects of theranekron on tendon repairs, compared to the control group, including weight gaining, mobility, reduced tissue inflammation during the treatment, they observed anti-inflammatory effect is a prominent feature of theranekron, as reported in the studies [12]. The anti-inflammatory effect of Theranekron could be attributed to its capability of inhibiting inflammation pathway and consequently enhanced tissue repair [12]. In healing process, inflammation is an inevitable phenomenon for mediator formation which in turn triggers reconstruction process $[7,9,10$, 12]. Chronic inflammation may cause cell deterioration due to stabilized PMNs which function as supportive against microorganisms. Other functions include mononuclear cell absorption and phygotosis of fibrins and debris. It is worth mentioning that lysosomal enzymes released by PMNs are influential in debris elimination [7].

In our study untreated control group as well as saline group showed inferior bone formation in comparison to Theranekron and autograft group. In the study by Oryan et al, in 2014, radiographic 
images and histopathologic studies showed that the defect site in the control group and normal saline group was filled with fibrous tissue. That is why, when bone defect is filled with fibrous tissue, bone formation is not allowed to be filled with fibrous tissue [20].

The present study has some limitations. Firstly, it is possible that the effects observed in the present study may not be a direct result of the theranekron but rather of the carrier. The authors could not investigate the exact mechanism of action of this reagent in the early phases of bone defect healing. Another point that could be pointed out as a limitation of this study was related to the solution of Theranekron. It seems alcohol has some adverse effects on repair processes and it would be of benefit if another control group were designed and the effects of alcohol solution alone were investigated. However, we diluted theranekron with $0.9 \%$ saline to reduce the adverse effects of alcohol solution on the defected area and the significantly better results related to the theranekron treated group may explain that the theranekron extract exerted its effects on bone healing.

\section{Conclusion}

As radiographs and histhopathology results indicated in the present study, the bone defect was filled with fibrous tissue in untreated and saline treated controls, which inhibits bone regeneration. Theranekron treated group showed almost similarly to autograft counterpart, but better than normal saline and untreated controls.

\section{Declarations}

\section{Acknowledgments}

The authors would like to thank the authorities of the Shahrekord University for their facilities providing and cooperation.

\section{Authors' contributions}

A Bigham-Sadegh, Siavash Sharifi and Yasamin Alavi carried out the operation. Ahmad Oryan conceived of the study design. Ahmad Oryan, A Bigham-Sadegh, Siavash Sharifi and Yasamin Alavi interpreted the data and drafted the manuscript. All authors read and approved the final manuscript.

\section{Competing interests}

The authors declare that they have no competing interests.

\section{Ethics approval and consent to participate}

All animals received humane care in compliance with the Guide for Care and use of Laboratory Animals (NIH publication No. 85-23, revised 1985). The study was approved by the local Ethics Committee of our 
Veterinary School. They were killed by intra-cardiac injection of $1 \mathrm{mg} / \mathrm{kg}$ Gallamine triethiodide (Specia Co., Paris, France).

Funding: There is no source of funding

Availability of data and material

The datasets used and/or analysed during the current study are available from the corresponding author on reasonable request.

Consent for publication Not applicable

\section{References}

1. Fitch R, Kerwin S, Sinibaldi KR, Newman-Gage H: Bone autografts and allografts in dogs. Compend Contin Educ Vet 1997, 19(5):558-578.

2. Ferguson JF: Fracture of the humerus after cancellous hone graft harvesting in a dog. J Small Anim Pract 1996, 37(5):232-234.

3. Dorea HC, McLaughlin RM, Cantwell HD, Read R, Armbrust L, Pool R, Roush JK, Boyle C: Evaluation of healing in feline femoral defects filled with cancellous autograft, cancellous allograft or Bioglass. Vet Comp Orthop Traumatol 2005, 18(3):157-168.

4. Stampa S: A field trial comparing the efficacy of sulphamonomethoxine, penicillin, and tarantula poison in the treatment of pododermatitis circumspecta of cattle. J S AFR VET ASSOC 1986, 57(2):91-93.

5. Gultiken N, Vural MR: The effect of Tarantula cubensis extract applied in pre and postoperative period of canine mammary tumours. J Istanbul Vet Science 2007, 2:13-23.

6. Muste A, Oana L, Beteg F, Ober C: Morphoclinical aspects in tarsal bursitis in cattles; surgical and medicamentous treatment. Bulletin UASVM Horticulture 2008, 65(2).

7. Sardari K, Kakhki EG, Mohri M: Evaluation of wound contraction and epithelialization after subcutaneous administration of Theranekron @ in cows. Comp Clin Path 2007, 16(3):197-200.

8. Albay MK, Sahinduran S, Kale M, Karakurum M, Sezer K: Influence of Tarantula cubensis extract on the treatment of the oral lesions in cattle with bluetongue disease. Kafkas Univ Vet Fak Derg 2010, 16:593-596.

9. Kacar C, Zonturlu AK, Oral H, Yildiz S, Ari UC: The effects of Theranekron (R) application on uterus involution and vaginal efluence in cows early puerperal period. Kafkas Univ Vet Fak Derg 2007, 13(1):11-15.

10. Cam Y, Kibar M, Atasever A, Atalay D, Beyaz L: Efficacy of levamisole and Tarantula cubensis venom for the treatment of bovine cutaneous papillomatosis. Vet Rec 2007, 160(14):486-488.

11. Richardson-Boedler C: The brown spider Loxosceles laeta: source of the remedy Tarentula cubensis? Homeopathy 2002, 91(3):166-170. 
12. Oryan A, Moshiri A, Raayat AR: Novel application of Theranekron® enhanced the structural and functional performance of the tenotomized tendon in rabbits. Cells Tissues Organs 2012, 196(5):442-455.

13. Kazemi D: Evaluation of ketamine, xylazine, acepromazine and diazepam combinations for anaesthesia in rabbits. Indian Journal of Veterinary Surgery 2002, 23:12-15.

14. Lane JM, Sandhu HS: Current approach to experimental bone grafting. Orthop Clin North Am 1987, 18:213-225.

15. Bigham-Sadegh A, Oryan A: Selection of animal models for pre-clinical strategies in evaluating the fracture healing, bone graft substitutes and bone tissue regeneration and engineering. Connect Tissue Res 2015(0):1-20.

16. Matos $\mathrm{M}$, Gonçalves R, Araújo F: Experimental model for osteotomy in immature rabbit. Acta Ortopédica Brasileira 2001, 9:21-26.

17. Roa DM, Bright RM, Daniel GB, McEntee MF, Sackman JE, Moyers TD: Microvascular transplantation of a free omental graft to the distal extremity in dogs. Veterinary surgery 1999, 28(6):456-465.

18. Bolander ME, Galian G: The use of demineralize bone matrix in the repair of segemental defect. $J$ Bone Joint Surg Am 1986, 684:1264-1274.

19. Enbergs $H$, Sensen B: Effectiveness of a homeopathic treatment of chronic endometritis in dairy cows. Prakt Tierarzt 2007, 88(7):534-+.

20. Oryan A, Bigham-Sadegh A, Abbasi-Teshnizi F: Effects of osteogenic medium on healing of the experimental critical bone defect in a rabbit model. Bone 2014, 63:53-60.

\section{Tables}

Table 1: Radiograph scoring based on Lane, Sandhu system 


\begin{tabular}{lc}
\hline \multicolumn{1}{c}{ Items } & Score \\
\hline Bone Formation & 0 \\
No evidence of bone formation & 1 \\
Bone formation occupying \%25 of defect & 2 \\
Bone formation occupying \%50 of defect & 2 \\
Bone formation occupying \%75 of defect & 3 \\
Bone formation occupying \%100 of defect & 4 \\
Union (Proximal, Superior, Distal/Inferior) & \\
Non union & 0 \\
Possible union & 1 \\
Radiographic/full union & 2 \\
Remodelling & 2 \\
No evidence of remodeling & 0 \\
Poor/weak remodeling & \\
Full remodelling & \\
\hline
\end{tabular}

Table 2: Radiographical findings for bone healing at every two weeks post-operative intervals

\begin{tabular}{|c|c|c|c|c|c|}
\hline \multirow{2}{*}{$\begin{array}{c}\text { Postoperative } \\
\text { Weeks }\end{array}$} & $\begin{array}{c}\text { Thranekron } \\
\text { group }\end{array}$ & $\begin{array}{c}\text { Normal saline } \\
\text { group }\end{array}$ & $\begin{array}{c}\text { Autograft } \\
\text { group }\end{array}$ & $\begin{array}{c}\text { Untreated } \\
\text { control group }\end{array}$ & \\
\hline 2 & $1(0-2)^{¥}$ & $1(0-1)$ & $5(1-5)^{+}$ & $0(0-1)$ & 0.02 \\
\hline 4 & $5(2-9)^{\S}$ & $1(0-5)$ & $5(5-9)^{\text {ฯ }}$ & $1(1-6)$ & 0.01 \\
\hline 6 & $9(8-9)^{¥ ¥}$ & $1(0-5)$ & $5(5-10)^{* *}$ & $1(1-6)$ & 0.004 \\
\hline 8 & $8(1-8)$ & $1(0-8)$ & $10(9-10)^{\text {ฯ }}$ & $4(1-9)$ & 0.005 \\
\hline
\end{tabular}


* Kruskal- Wallis non parametric ANOVA, when P value was less than 0.05 complementary MannWhitney U test was done and P value less than 0.05 was considered statistically significant

+ a significant difference between autograft group and the two groups of untreated and saline treated controls that autograft group was superior to mentioned groups ( $\mathrm{P}=002$, $\mathrm{p}=0.04$, respectively)

$¥$ a significant difference between Theranekron group and untreated control that Theranekron group was superior to untreated control groups $(p=0.04)$

$\boldsymbol{\Upsilon}_{\mathrm{a}}$ significant difference between autograft group and saline treated group that autograft group was superior to saline treated group $(p=0.01)$

$\S_{\mathrm{a}}$ significant difference between Theranekron group and two groups of untreated and saline treated controls that theranekron group was superior to two mentioned groups $(p=0.02, p=0.03$, respectively)

** a significant difference between autograft and saline treated groups that autograft group was superior to saline treated group $(p=0.01)$

$¥ ¥$ a significant difference between Theranekron group and two groups of untreated and saline treated controls that theranekron group was superior to two mentioned groups $(\mathrm{p}=$ $0.006, \mathrm{p}=0.008$, respectively)

$\boldsymbol{\top} \boldsymbol{\Phi}_{\text {autograft }}$ group significantly outperformed untreated, saline treated controls and Theranekron groups $(p=0.009, p=0.006, p=0.006$, respectively)

Table 3: Histopathological findings (sum of histopathological criteria) for bone healing at various groups 


\begin{tabular}{|c|c|c|c|c|c|}
\hline & \multicolumn{3}{|c|}{ Median (Minimum-Maximum) } & \multicolumn{2}{|r|}{$\mathrm{P}^{*}$} \\
\hline & $\begin{array}{c}\text { Thranekron } \\
\text { group }\end{array}$ & $\begin{array}{c}\text { Normal saline } \\
\text { group }\end{array}$ & $\begin{array}{c}\text { Autograft } \\
\text { group }\end{array}$ & $\begin{array}{l}\text { Untreated } \\
\text { group }\end{array}$ & \\
\hline $\begin{array}{l}\text { Sum of } \\
\text { histopathological } \\
\text { criteria }\end{array}$ & $5(2-6)$ & $1(1-7)$ ๆ & $6(2-6)$ & $1(0-3)^{\pi}$ & 0.05 \\
\hline
\end{tabular}

* Kruskal- Wallis non parametric ANOVA, when P value was less than 0.05 complementary MannWhitney $\mathrm{U}$ test was done and $\mathrm{P}$ value less than 0.05 was considered statistically significant

I untreated and saline group was significantly inferior to autograft and Theranekron groups $(p=0.004)$

\section{Figures}
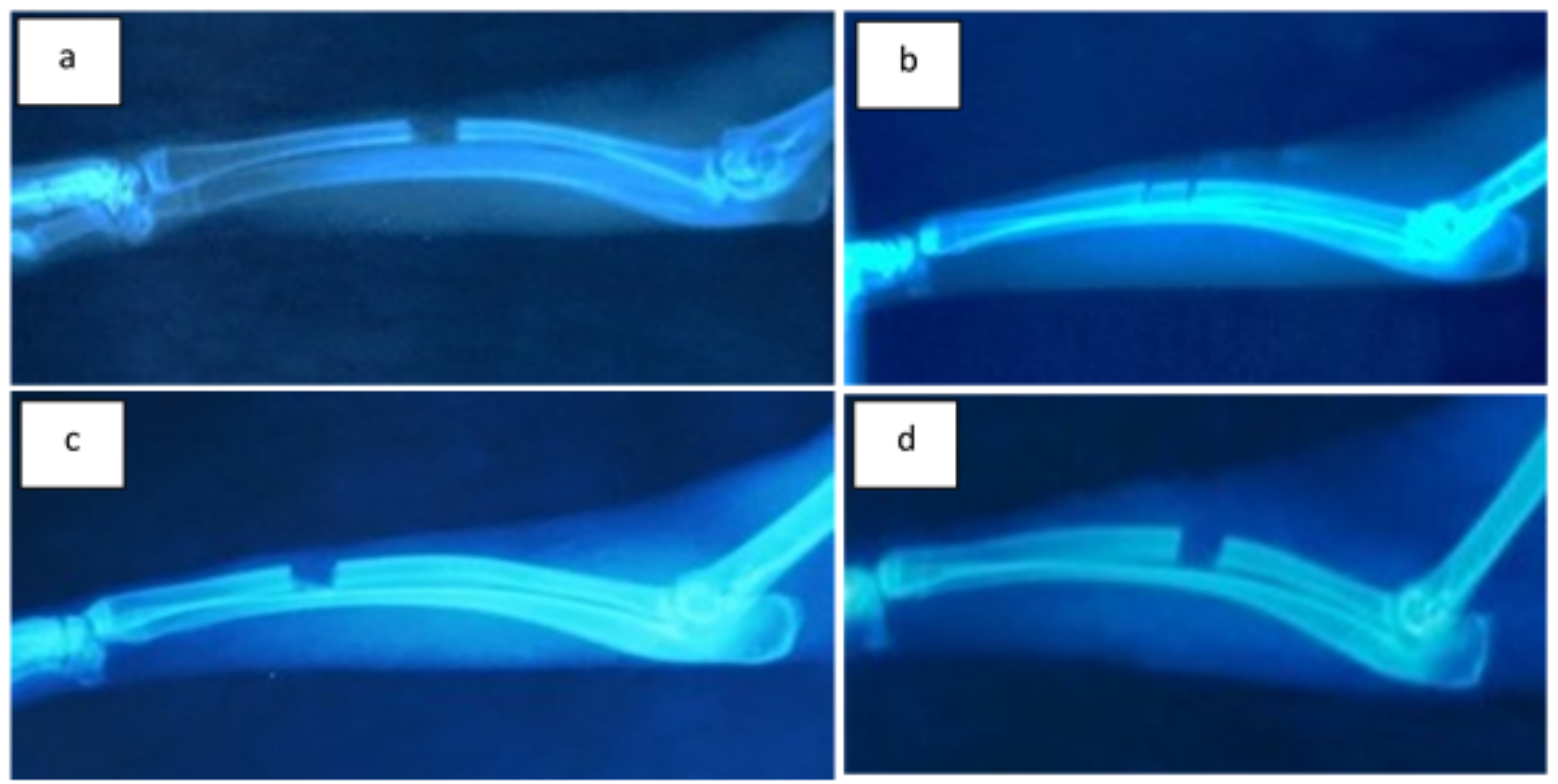

\section{Figure 1}

Radiographs through 2nd week: (a)Theranekron, (b) autograft, (c) normal saline treated controls, (d) untreated controls 


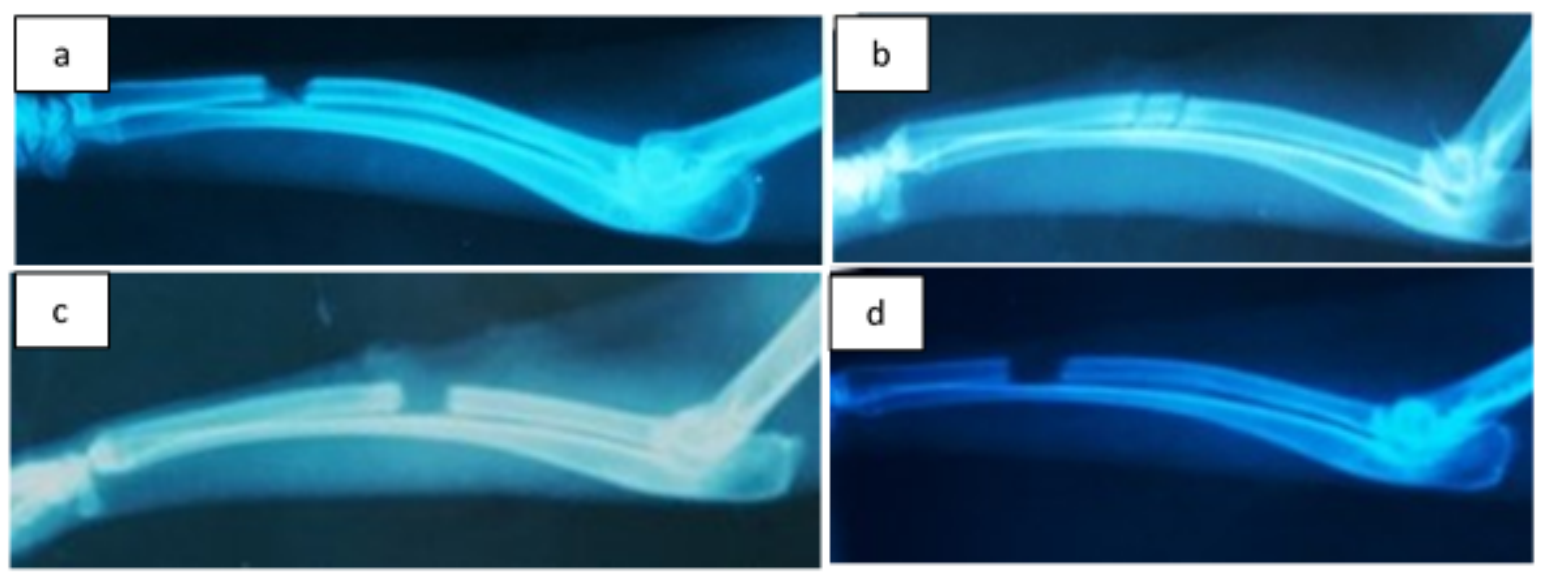

\section{Figure 2}

Radiographs through 4th week: (a)Theranekron, (b) autograft, (c) normal saline treated controls, (d) untreated controls
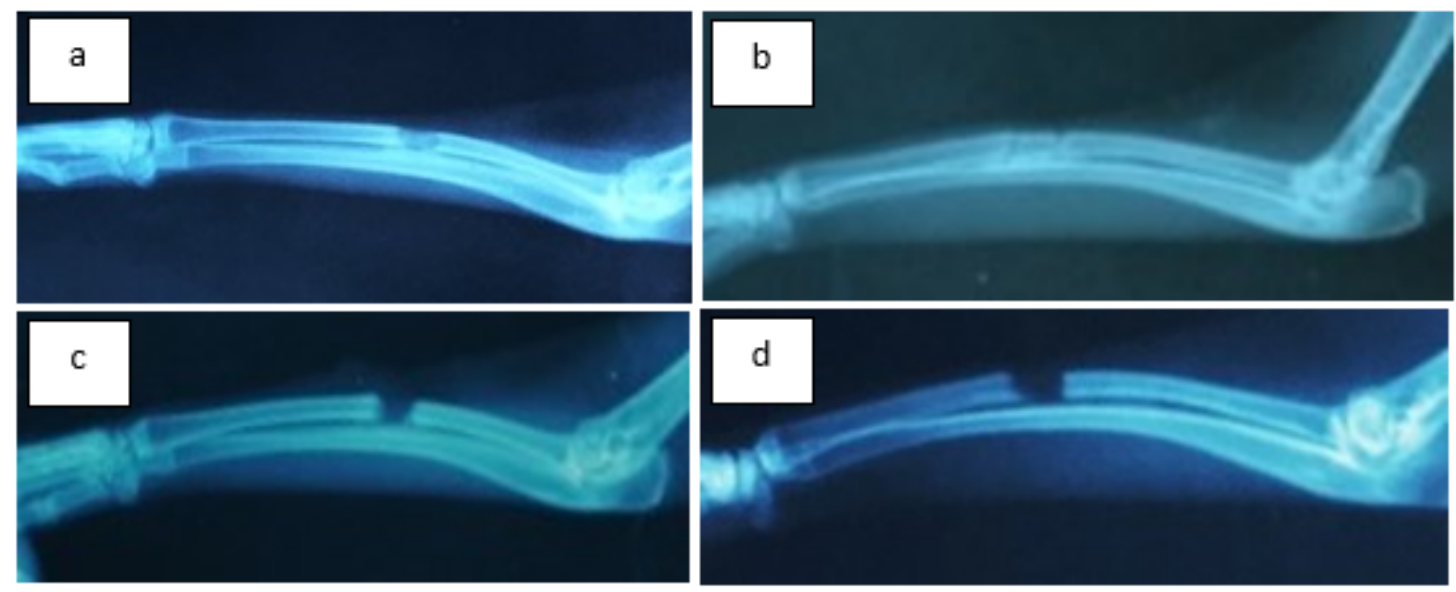

\section{Figure 3}

Radiographs through 6th week: (a)Theranekron, (b) autograft, (c) normal saline treated controls, (d) untreated controls

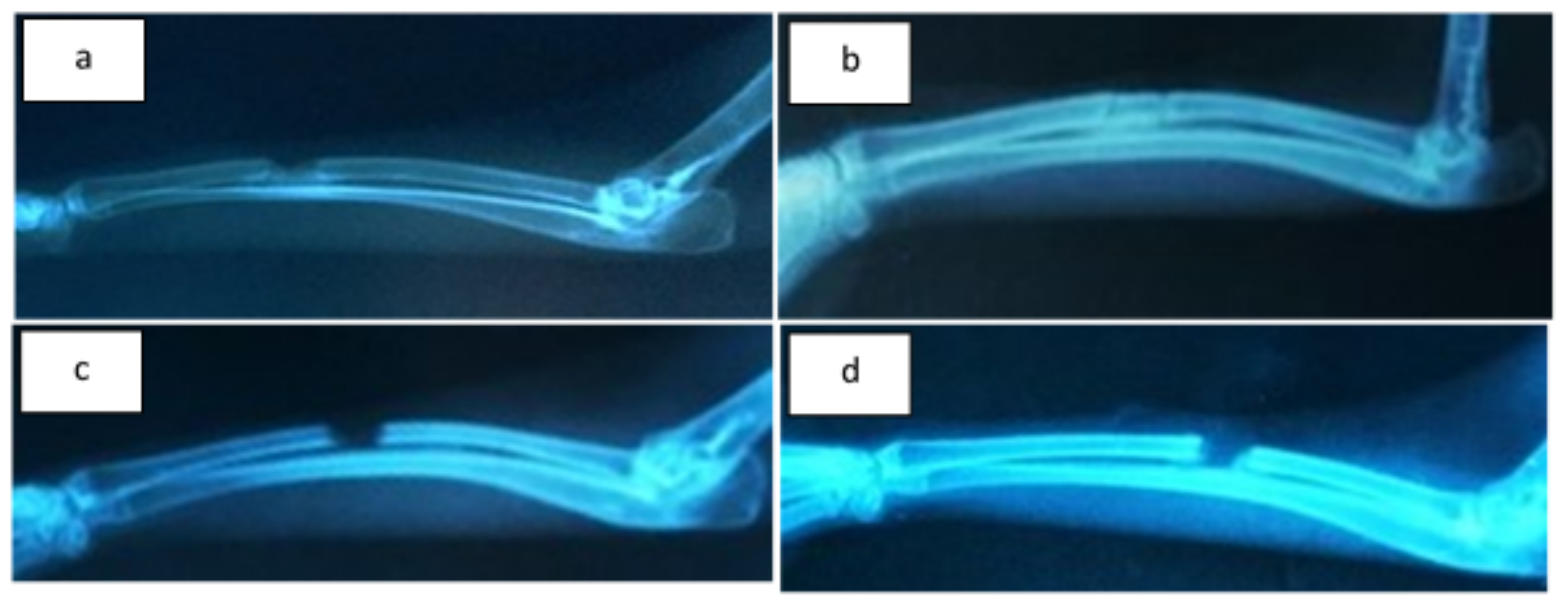


Figure 4

Radiographs through 8th week: (a)Theranekron, (b) autograft, (c) normal saline treated controls, (d) untreated controls
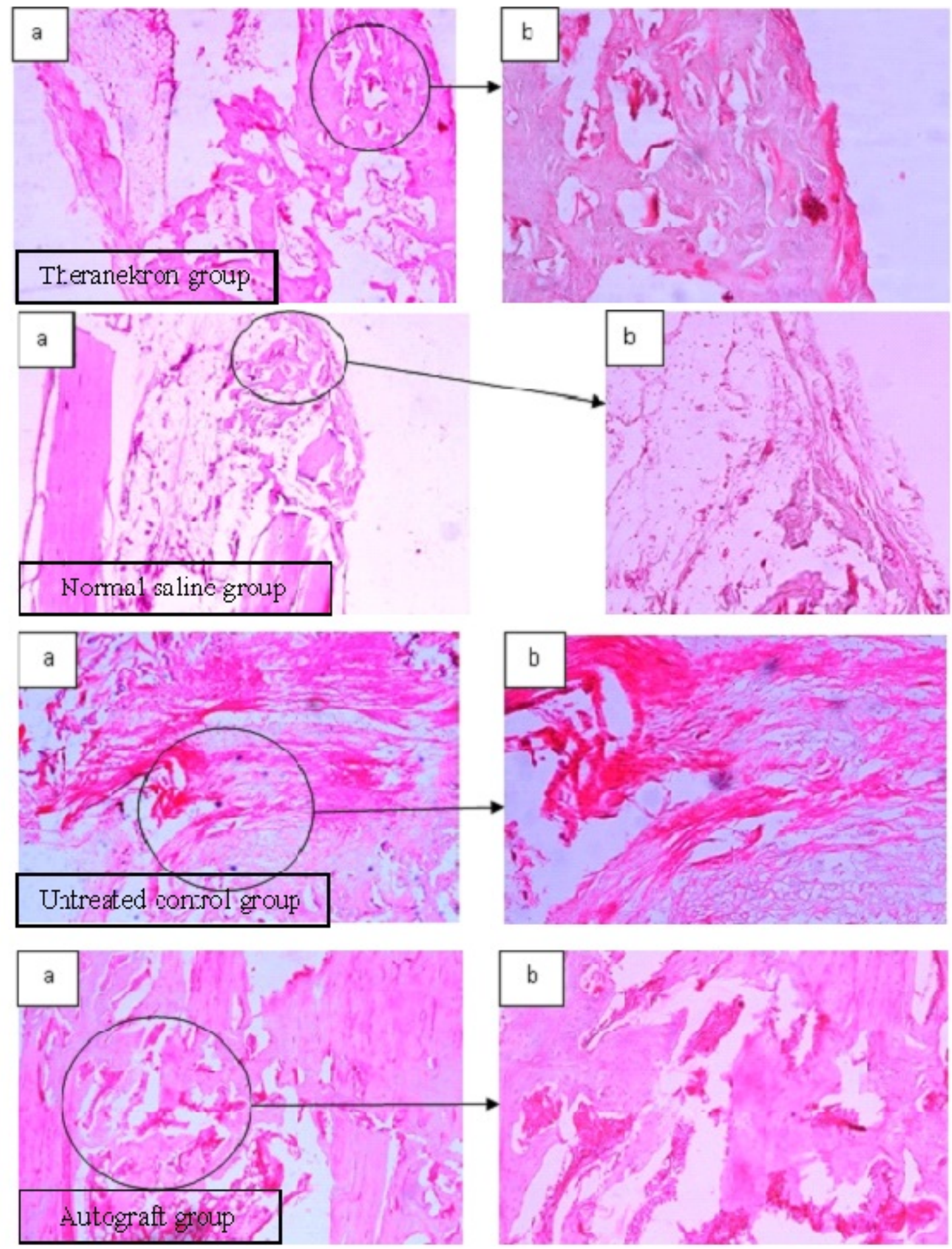

\section{Figure 5}

Histopathological signs in Theranekron group, terabecule bone formation, in normal saline treated and untreated groups, fibrous tissue formation and in autograft group, bone marrow regeneration, thick trabecular formation were observed. H \& E (a: 4x, b: 10x) 


\section{Supplementary Files}

This is a list of supplementary files associated with this preprint. Click to download.

- ARRIVEChecklist.docx 